\title{
STRATEGIC BUSINESS MODEL TYPOLOGIES EVIDENT IN THE CHINESE REAL-ESTATE INDUSTRY
}

\author{
Guiwen LIU ${ }^{1}$, Kaijian LI ${ }^{1,2,}$, Asheem SHRESTHA ${ }^{3}$, Igor MARTEK ${ }^{3}$, Yang ZHOU ${ }^{1}$ \\ ${ }^{1}$ School of Construction Management and Real Estate, Chongqing University, Chongqing 400045, China \\ ${ }^{2}$ School of Architecture and Urban Planning, Chongqing University, Chongqing 400045, China \\ ${ }^{3}$ School of Architecture and Built Environment, Deakin University, Geelong, Australia
}

Received 3 October 2016; accepted 17 December 2017

\begin{abstract}
The Chinese real estate industry has emerged over recent decades as one of the key drivers of Chinese economic growth and attracted thousands of players nationwide. Yet, despite the continuing importance of the real-estate industry in China, there has not been any work done to identify nor describe the strategic business models used by enterprises within the sector. This study fills this gap in the literature. This paper begins by building a framework for studying the strategic business models used within the Chinese real-estate industry, and then goes on to identify the generic models that exist in the industry. A two-step cluster analysis of 117 Chinese real-estate companies was carried out over seven parameters identified in the literature as impacting business models: 1) clients, 2) products offered, 3) market locale, 4) financial structure, 5) value chain embeddedness, 6) core competency, and, 7) revenue source. Five generic strategic business models that characterize the Chinese real-estate industry were identified: 1) commercial property model, 2) government servicing model, 3) cost efficiency model, 4) asset management model, and, 5) high-turnover model. The findings will assist industry practitioners in evaluating and informing their own competitive positions within the Chinese real-estate industry.
\end{abstract}

Keywords: real-estate, business strategy, business model, business competition, cluster analysis, China.

\section{Introduction}

Companies must have a basis on which to conduct business if they are to capture market share, sell products and services, and achieve a reasonable return on investment. This ability has been described as a 'strategic competitive advantage, and in its simplest form reduces to the capacity of a firm to offer a product or service, either cheaper than that of competitors, or, recognizably and desirably different from competitors (Porter, 1985). Where the product or service on offer is different, that difference must impart added value to the consumer over and above the premium the consumer pays the supplying firm for that difference. Where the product or service on offer is cheaper, that reduced price must come from the firm's ability to source inputs of labor, capital or materials more cheaply, or, by superior innovative or technological means, transform those inputs into a finished output through a more costeffective process. There are of course many ways in which firm's may achieve these advantages; and indeed, numerous firms are able to sustain themselves competitively within a market but focusing on one aspect or another of the cost reduction, or quality differentiation process. Most critically, a firm must be able to identify the mechanism, or 'business formula', by which it can generate superior profits through the delivery of differentiated or cheaper outputs. This recipe for generating profits (higher revenue streams over cost streams) has come to be known as the 'business model' (Ovans, 2015).

The business model consists of three broad areas around which management will focus its efforts at value creation (Mangematin, Ravarini, \& Scott, 2017; Thomas, 2001). Firstly, costs will be reduced where inputs coming into the firm can be sourced more cheaply. Secondly, revenues will be increased where outputs going into the market can be sold in large volumes and at higher prices. Thirdly, profits will be improved where the added value process within the firm can be made to convert inputs more efficiently into better quality, more highly prized outputs for which consumers are willing to pay a greater price. A business plan, therefore, documents the firm's organizational activities, resources, and processes by which value creation, capture and distribution is achieved (Pan \& Goodier, 2012).

${ }^{*}$ Corresponding author. E-mail: likaijian@cqu.edu.cn 
Though business strategies and business models are widely accepted tools in business practice, and amongst the most commonly researched areas in business studies, investigations have largely been confined to the manufacturing and services sectors (Winterhalter, Weiblen, Wecht, \& Gassmann, 2017). On the other hand, business strategy in the real-estate industry and related services, has attracted almost no attention. The real-estate delivery is unlike manufacturing where the product is replicated incessantly, and that buildings are to a greater extent unique, while the factory itself is mobile and not the product, it is not surprising that these works uncover strategies unique to the real-estate sector. Recent works by Martek and Chen $(2013,2014)$ are an exception and have explored the strategies employed by foreign firms operating within the Chinese real-estate industry. However, these studies are limited in their applicability since they concern global developers looking to secure off-shore market-share.

Over the past three decades, the Chinese real-estate industry has been at the forefront of China's economic growth, providing the infrastructure, commercial facilities and utilities that provide the foundation on which Chinese economic successes have been forged. Indeed, the real-estate industry that delivers the finished stock of built assets to the Chinese market operate within the most competitive sector of the Chinese market. Until now, however, no study has been undertaken to investigate the business models used by Chinese real-estate firms in establishing their competitive strategies. Given that real-estate is such a crucial industry in China, responsible for much of the country's GDP growth, and given that China's growth has entered a mature phase with the inevitable economic downturn nearing, an understanding of the business models used by real-estate firms within the Chinese real-estate industry is long overdue. This study aims to fulfill this knowledge gap.

Thus, this paper aims to build a framework for studying the strategic business models used within the Chinese real-estate industry, and then identify the generic models that exist in the industry. Data on 117 companies operating in the Chinese real estate industry is analyzed centering on key parameters of strategic business models and a two-step cluster analysis is performed to explore and recognize the dominant strategies adopted by companies to compete in the market. The findings provide significant implications for practitioners to understand how companies can maintain the strategic advantage in the highly competitive Chinese real-estate industry.

\section{The business model concept and definition}

Despite the term's familiarity, and its ubiquitous usage in business, there is in fact no widely agreed definition of the concept of 'business model'. It is associated with financial analysis, as a means for justifying increasing debt burdens, such as when seeking loans from banks. It is associated with entrepreneurial analysis, as a means for articulating the viability of a new venture. It is associated with market- ing analysis, as a means for scrutinizing the introduction of a new product, or the expansion of existing products into new markets. Common to all these usages, the business model defines the business logic underlying the strategic viability of the firm, long term (Sako, 2012). More broadly, it may also be considered the rationale by which an organization creates, captures and delivers value. This value may be financial, but it may also accrue as social, cultural or economic benefit (Osterwalder \& Pigneur, 2005).

In the management literature, the term 'business model' was first coined by computer specialists in the context of modeling marketing systems and innovative networks (Sako, 2012; Wirtz, Schilke, \& Ullrich, 2010; Magretta, 2002; Moore, 2004; Yuan, 2007). As the modeling grew more complex, these networks were expanded to incorporate a range of micro-economic actors, such as competitors, suppliers, and customers, as well as macro-economic factors, such as economic cycles, financial markets, and research developments (Doganova \& Eyquem-Renault, 2009; Osterwalder \& Pigneur, 2005). Arising from this ability to make sense of complexity, the business model emerged as a tool to analyze, formulate and communicate strategic choices. Indeed, the communicative power of the tool, and its potential to persuade through rational analysis imputed to the business model a great deal of credibility, explaining its now popular use in strategic management culture, literature and practice (Casadesus-Masanell \& Zhu, 2010; Dahan, Doh, Oetzel, \& Yaziji, 2010; Shafer, Smith, \& Linder, 2005; Weng, 2004). In its essence, the business model articulates the internal source of a firm's advantage and how this advantage creates value (Brettel, Strese, \& Flatten, 2013). In creating this value, the model will also describe a firm's external interactions and internal activities that combine to bring this value into realization (Schaltegger, Lüdeke-Freund, \& Hansen, 2013). In fields employing innovative technologies, the business model was linked with developmental plans to bring these new technologies to market, and to find strategies by which these technologies could be maximized for commercial gain (Wirtz et al., 2010; Teece, 2010). The business model has been used to evaluate enterprise performance and has been used as a basis for enterprise classification (Lambert \& Davidson, 2013; Li, Zhou, Shrestha, \& Liu, 2018). Overall, the key terms associated in the management literature with the concept of the business model are 'value,, 'business strategy', and 'economic outcome.' Considering this range of insight, the following definition is proposed:

\footnotetext{
"The Business Model is the logic of how interrelated decision variables in the areas of business strategy, value creation and delivery, are addressed to create corporate competitive advantage."
}

In the area of real-estate management, the concept of the 'business model' appears only implicitly. This may be explained by the confusion which arises between the terms 'project management', and 'business management'. 
Much of the management literature that is devoted to realestate management focuses on the project level. This sits in contrast with the extensive enterprise level research which infuses manufacturing management literature. Partly this is due to the complex and unique nature of real-estate projects, which, because of the relatively large risks, huge resource consumption and extensive investment costs associated with these projects, claim the lion's share of attention (Fellows \& Langford, 1980). Nevertheless, several attempts have been made to establish the relationship between real-estate firms' business models and real-estate development activities. Indeed, both Callcutt (2007) and Ball (2010) describe the very process of real-estate delivery mode in terms of a 'business model.' Goodier and Pan (2011) take on a more traditional manufacturing perspective of the concept. For them, a real-estate business model addresses how a real-estate firm makes decisions regarding risk, financing, processes and activities. Brege, Stehn, and Nord (2014) extend this viewpoint envisioning the business model as composed of five elements: prefabrication technology, systems, building process, end customer, and complementary resources. The International Energy Agency 'renewable energy technology deployment group' (2013) view built environment business models simply as business strategies that deliver revenue streams, foster core competencies, establish a customer base, and ensure a viable sales channel.

Preoccupation with real-estate management at the project level, however, does not preclude the necessity for a business model at the firm level; individual project success is not synonymous with enterprise level success. The business strategy of a real-estate company must address the key questions of organizational structure, process activities, resources at hand, financing (Liu et al., 2016a), target product (Brege et al., 2014), core competencies (Tykkä et al., 2010), target customer (Pan \& Goodier, 2012), and delivery mode (Brege et al., 2014), among others, just as are faced by firms in any other industry. Of course, the unique nature of real-estate industry output will shift the emphasis somewhat. Specifically, the mode of real-estate delivery will loom particularly large, as Callcutt (2007) has observed, suggesting that four delivery modes dominate the real-estate industry: current trader model, investor model, self-builder model, and, build-for-sale model. Other researchers have identified lean construction, and the integration of information and communication technology, as key areas through which competitive advantage might be obtained within the real-estate industry $(\mathrm{Li}$, Guo, Skibniewski, \& Skitmore, 2008; Tykkä et al., 2010; Pan \& Goodier, 2012). Company finances have also been identified as key ingredients in real-estate enterprise business models (Seaden, Guolla, Doutriaux, \& Nash, 2003; A. Pekuri, Suvanto, Haapasalo, \& L. Pekuri, 2014; Johnson, Christensen, \& Kagermann, 2008), market position by others (Goodier \& Pan, 2011; Hamel, 1998; Brege et al., 2014; Liu, Li, Zhao, \& Mao, 2017), and others yet have made the point that various stakeholder interests and those of other agents within the real-estate industry, too, can have a significant effect on the strategic outcomes of real-estate enterprises (Tykkä et al., 2010). For the purposes of this study, then, the following definition is offered:

\begin{abstract}
"The real-estate Business Model is the logic of how the decision variables, available the various stakeholders to a real-estate enterprise, in the areas of business strategy, value creation and delivery, are addressed to create corporate competitive advantage."
\end{abstract}

\section{The real-estate business model framework}

Two major theoretical streams are evident within the academic literature which explain how business models deliver value. The first is the 'resource based view of the firm' (Penrose, 1959; Wernerfelt, 1984; Barney, 1991), that regards a firm as a bundle of resources, which when combined by internal competencies determined by a set of competitive advantages, produce valuable output. The second is the 'transaction cost economics perspective' (Morris, Schindehutte, \& Allen, 2005), which states that value is created through transactional efficiencies. Of course, both visions have merit, and it can be agreed that firm value-added capabilities arise from both resource combining and transaction efficiency behaviors (DaSilva \& Turkmen, 2014). Of greater interest, however, is how this value adding capabilities are realized in practice. Abdelkafi, Makhotin, and Posselt (2013) developed a value centered framework to describe the interaction of components of the business model. Eight such components pertinent to firms' active in real-estate construction were identified through the academic literature. These are: 1) product or service offered, 2) competitive strategy, 3) value proposition, 4) target customer, 5) resources and capabilities, 6) internal organization and activities, 7) firm's role in the value chain, and, 8) revenue generation logic. Based on these theories, and the components which impact a firm's value adding capabilities, a conceptual business model framework, pertinent to the real-estate industry, has been developed, and is presented as Figure 1.

A firm's business model begins first with a strategy (Smith, Binns, \& Tushman, 2010). On the one hand, this strategy must offer a product or service that is in demand, and on the other hand, do so in a competitive way which cannot be readily duplicated by competitors. In other words, the firm must be able to produce something others cannot. This unique capability may be the result of the control of resources, patents, technologies, distribution channels, skill sets, or simply by virtue of geographic closeness to the target customer. This control of resources, patents or technologies that competitors lack, defines a firm's core competency, while relative proximity to customers gives the firm market locale leverage.

Secondly, the product or service offered must be of value to a sufficient number of customers. That is, the price of 


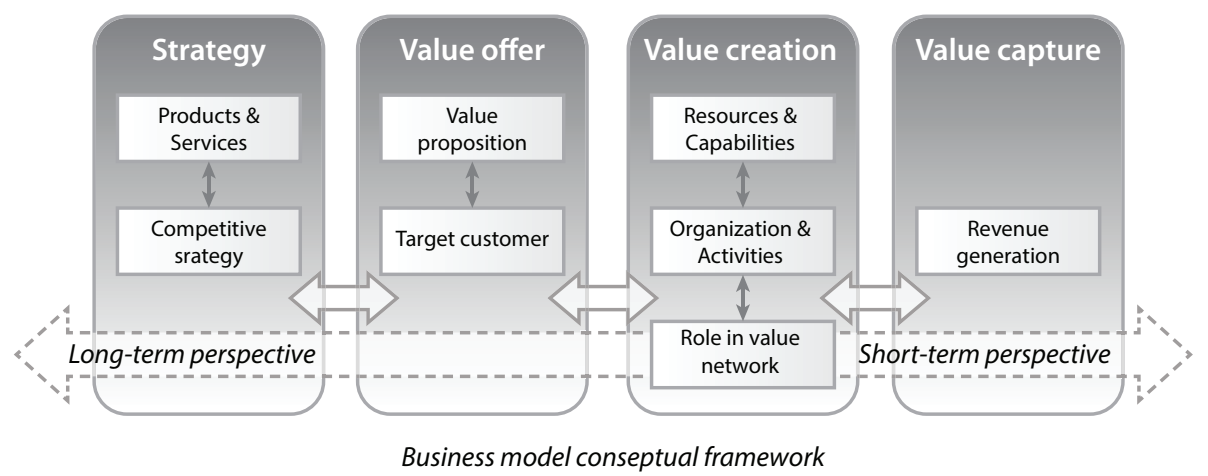

Figure 1. Conceptual framework of a real-estate enterprise business model

the product must be lower than the price customers perceive the product to be worth to them. Here the business plan must identify that demographic within the greater market who both value the product and who will pay the asking price. Again, the perceived value of the product may arise because the firm offers it at a price lower than competitors, or it may arise because the firm offers it sufficiently differentiated from cheaper alternatives (Porter, 1985). The combination of these factors defines the client base the firm services, along with the unique range of product offerings by which those clients are served.

Thirdly, the firm now must convert input resources, for which it pays a cost, into a higher value-added output, for which it receives a price (Smith, Binns, \& Tushman, 2010). Of course, the price received for the product sold must be higher than the cost paid for the factors of production used by the firm in making the product. This difference - revenue minus costs - is the firm's profit. Three elements play into the firm being able to limit costs here. If the firm can source input resources, such as building materials, more cheaply than competitors, it has an advantage. If it can assemble those resources more efficiently, in less time, with less errors, or with less waste, if has a further advantage. Moreover, if the firm can positively influence the quality or cost efficiency of up-stream suppliers or down-stream buyers, this will contribute to the overall competitiveness of the value-chain within which the firm operates. Where the firm chooses to emphasize its efforts - up-stream, down-stream, or internally - along with the extent to which it is active across these areas, defines its value chain embeddedness. Similarly, its areas of activity will define its revenue source.

Finally, value capture refers to the firm's cost structure, such as its combination of fixed and variable cost elements, and the means by which the firm extracts profits from the financial side of its operations (Casadesus-Masanell \& $\mathrm{Zhu}, 2010$ ). The means by which a firm extracts a maximal profit (whether by cost minimization, premium pricing, supplier controls, monopoly arrangements, tax minimization, policy incentive capture, other measures, or any combination of these), will influence the firm's operational and financial structure.

\section{Research methodology}

117 Companies active in the Chinese real-estate industry formed the basis of the sample. Research literature on business models was reviewed, and seven variables identified as impacting on those models were extracted. Data on those variables across those companies was then collected in a two-stage process: published material was analyzed and interviews were conducted. Statistical cluster analysis of the variables data was then utilized to determine like and unlike strategies, with five generic strategic business typologies finally identified as characterizing the Chinese real-estate industry. To our knowledge, this study is the first to develop a taxonomy of business models for the real-estate industry, and only the second to use cluster analysis to determine strategic typologies using a large data set; the first by Martek and Chen $(2013,2014)$, establishing the validity of this approach.

\subsection{Real-estate company sample}

Based on the following two considerations, this paper chooses listed companies as research samples: (1) According to the China National Bureau of Statistics Yearbook (2016), there is a total of 94,197 real estate enterprises in China. For the purposes of this study, 70\%, or more total revenues of the identified firms should be generated from real-estate development activities. However, it is difficult to quantify the propositions of revenues of non-listed companies. Taking into account the availability and accuracy of the data, this study only selected listed companies as research samples; (2) compared with non-listed companies, listed companies are more successful enterprises in the industry. The examination of listed companies' strategic business models should provide real-estate practitioners with more insightful knowledge for furthering their understanding of how firm's find and maintain the strategic advantage necessary to profitability and survival in the highly competitive Chinese real-estate industry. Martek and Chen (2013) and Timmers (1998) also adopt the similar sampling strategy.

At the time of this study, 143 real-estate enterprises were identified as listed and active within the real-estate 
sector in China. For the purposes of this study, a firm qualified as a real-estate enterprise where $70 \%$, or more, of its total revenues were generated from real-estate development activities. Consequently, on the basis of this inclusion threshold criteria, 26 firms were deemed ineligible for consideration and were dropped, leaving the remaining 117 firms (see the Appendix 1) as the real-estate enterprise sample on which this study is based.

\subsection{Real-estate business model variables}

In order to establish the range and nature of the strategic business model typologies used by real-estate firms, it was first necessary to identify those variables which inform business model formulation. This study reviewed the academic journals stored in Elsevier, Science Direct and other recognized data bases, using a range of search terms, over the years 1998 to 2016, inclusive. Of the numerous articles retrieved, publications by Brege et al. (2014), Pan and Goodier (2012), and Chesbrough (1996), stand out as particularly helpful in this regard. Ultimately, seven parameter variables that inform business model formulation, and the strategic orientation encapsulated within them, were identified. They are: 1) clients, 2) products offered, 3) market locale, 4) financial structure, 5) value chain embeddedness, 6) core competency, and, 7) revenue source. See Table 1.

1. Clients: This variable was used primarily to measure the enterprise customer groups. Assessing the income of target customers, which were derived from corporate annual reports, the target customers were divided into 'ordinary customers' (ordinary-income groups), 'high-end customers' (high-income groups), and 'integrated customers' (both ordinary and high-income groups).

2. Products offered: This variable refers to the construction product types offered by the enterprise. An analysis of the income data obtained from the corporate annual reports regarding the enterprises' main businesses, reveal that they were divided into: (i) residential oriented; (ii) commercial oriented; and (iii) others. If residential construction accounted for more than $70 \%$ out of the main business income for the enterprise, the enterprise was classified as 'residential oriented'. If commercial buildings accounted for more than $70 \%$ out of the main business income for the enterprise, the enterprise was classified as 'commercial oriented. Those enterprises with $70 \%$ of their income not being generated from either residential or commercial construction, were classified as 'others'.

3. Market locale: This variable was used to identify the proportion of sales income based on the location of the enterprises' market. The proportion of domestic sales income and the proportion of foreign sales income was used as the basis of classification. In addition, regional divisions were determined according to the administrative regions in China, i.e., East China, North China, South China, Central China, Northeast, Southwest, and Northwest. Enterprises whose regional sales accounted for more than $70 \%$, were classified as 'local leading type', while the others were classified as 'domestic leading type'.

4. Financial structure: This variable was used to measure whether the corporate finance structure was adequate to support the sustainable development of enterprises. If the debt-to-assets ratio index was less than $40 \%$, the enterprise was classified as 'riskadverse'. If the debt-to-assets ratio index was greater than $40 \%$, but less than $70 \%$, the enterprise was classified as 'risk-neutral', and if the debt-to-assets ratio index was higher than $70 \%$, the enterprise was the classified as 'risk-seeking. Risk averse enterprises may not use full leverage of funds to create greater value for shareholders. Risk neutral enterprises use

Table 1. Variables identified as impacting real-estate construction enterprise business models, dimensions, precedents and data sources

\begin{tabular}{|c|c|c|c|c|}
\hline Logical level & Variable & Dimension & Precedent & Data source \\
\hline \multirow[t]{3}{*}{ Value orientation } & Clients & Ordinary; high-end; integrated & Brege et al. (2014) & Interview \\
\hline & Product offered & $\begin{array}{l}\text { Residential oriented; commercial } \\
\text { oriented; others }\end{array}$ & Brege et al. (2014) & $\begin{array}{l}\text { Financial statement, } \\
\text { interview }\end{array}$ \\
\hline & Market locale & $\begin{array}{l}\text { Local leading type; domestic leading } \\
\text { type }\end{array}$ & Self-designed & Financial statement \\
\hline \multirow[t]{3}{*}{ Value creation } & Financial structure & $\begin{array}{l}\text { Risk-adverse; } \\
\text { risk-neutral; } \\
\text { risk-seeking }\end{array}$ & $\begin{array}{l}\text { Pan and Goodier } \\
(2012)\end{array}$ & Financial statement \\
\hline & $\begin{array}{l}\text { Value chain } \\
\text { embeddedness }\end{array}$ & $\begin{array}{l}\text { Upstream; peer; downstream; upper } \\
\text { and peer; peer and downstream; } \\
\text { upstream and downstream; and the } \\
\text { industry-wide }\end{array}$ & Self-designed & Interview \\
\hline & Core competency & External; internal; integrated & Chesbrough (1996) & Interview \\
\hline Value source & Revenue source & $\begin{array}{l}\text { Sales oriented; rental oriented; } \\
\text { integrated }\end{array}$ & Chesbrough (1996) & Financial statement \\
\hline
\end{tabular}


funds to generate medium levels of earnings. Risk seeking enterprises may take more financial risks by making full use of financial leverage to obtain high profits.

5. Value chain embeddedness: This variable was used to measure the cooperative alliancing relationships between the enterprise and stakeholders (such as government, contractors, suppliers, investors, etc.). The industrial chain theory divides stakeholders into the upstream stakeholders (such as government and financial institutions), the peer stakeholders (such as designers and contractors) and downstream stakeholders, (such as business partners and terminal customers). We examined whether sample enterprises had established long-term cooperative relationship with these three types of stakeholders. Consequently, this study classified the relationship between enterprises and stakeholders into seven categories: the 'upstream cooperation type'; the 'peer cooperation type'; the 'downstream cooperation type'; the 'peer-to-upstream cooperation type'; the 'downstream-to-peer cooperation type'; the 'upstream and downstream cooperation type'; and, the 'industry-wide cooperation type'.

6. Core competency: This variable was used to compare the competitive advantage between enterprises and their competitors. From evaluations of company annual reports and industry data, it was possible to determine the core capabilities of the real-estate enterprises. Generally, main competencies included such things as employee skill sets, supplier relations, government sponsorship, technical resources and capabilities, sources of capital, management capability, brand influence, and so on. This variable was further investigated using surveys, with the emergent findings arising from the two methods highlighting three competency orientations. An 'external competency enterprise strengths' lie in the ability to integrate with the industry value chain regarding the interests of the relevant parties (including upstream and downstream industries, consumers and government), and the relevant resources (including land, funds, raw materials, etc.). An 'internal competency enterprise strengths' lie in their own self-generated management and technological capabilities, including human resources, life cycle management and financial and systems controls. An 'integrated competency enterprise strengths' lie in the integration of both external and internal capabilities.

7. Revenue source: This variable was used to measure the enterprise's main source of income. Through an analysis of the annual income for the listed enterprises, it was found that the real-estate business revenue sources include property sales, property rental, hotel experience, property management, design and decoration, etc. Based on the data, the real-estate enterprises' source of income was divided into: 'sales oriented'; 'rental oriented'; 'integrated type'. Enterprises with more than $50 \%$ of their income coming from property sales were classified as 'sales oriented', while enterprises with more than $50 \%$ of their income coming from property rental was classified as 'rental oriented'. All other enterprises were classified as 'integrated type'.

\subsection{Business model variables data collection}

Two types of data were accessed. Firstly, published data was collected where possible and secondly, interviews were conducted (where the first option was not applicable). Specifically, where the required data was available from existing published documents, these were used. It included data from corporate annual reports as well as other internally published sources such as prospectus publications and corporate websites. Data on clients, products offered, market locale, financial structure and revenue source were publicly available and was collected through a desk study. However, data on core competency and value chain embeddedness were not available from the existing data sources, and thus, were obtained directly through interview surveys with company representatives.

The questionnaires were designed using a seven point Likert scale. Given the potential for subjective bias impairing the questionnaire data, only experienced experts, with at least five years' direct experience in real-estate business planning at senior management or senior academic level, were consulted. Initially, a focus group of industry experts was asked to collectively assess all the candidate firms and place them into categories of best fit. Subsequently, fifteen company representatives were asked, in interviews, to assess the firms against the same categories. Where discrepancies between the focus group assessment of a firm conflicted with the assessment provided by the industry practitioners, further discussion ensued to establish a rationale for the discrepancy and to resolve the matter. Statistical checks of the data thus collected were validated.

\subsection{Business model cluster analysis}

Once all the data across the seven parameter variables was collected, and validated, for all the 117 enterprises that comprised the sample set, the data was processed using an SPSS 'two-step cluster' method. In an 'n' sample set, clusters can be generated across the full spectrum from 1 to 'n'. Neither extreme is useful, since the aim of cluster analysis is to develop a taxonomy of representative strategic typologies, against which the strategic behavior of firms can be compared and to which firms can be allocated. Effective cluster analysis, therefore, must not only determine the essential distinguishing features that characterize one cluster from another, but also must identify the optimal number of clusters such that meaningful comparisons can be made. The 'two-step' method has the capacity to determine this optimal number of clusters. Moreover, it can process both continuous and categorical variables, 
defining normal densities for continuous variables, and multinomial probability mass functions for categorical variables.

In the first step of the two-step process, data are scanned and, depending on a dynamic distance criterion, are allocated into existing clusters, or, set aside to form a new cluster. As new data is processed, the cluster allocation of previously processed data is reviewed to ensure earlier data allocations are optimized. The results are codified into an algorithm which describes the allocation of all variables across ' $n$ ' possible clusters. In the second step, the optimal number of clusters are then determined from the 'n' possibilities. Finally, a 'silhouette coefficient', which measures the density of all the data in a cluster, is calculated to assess the goodness of fit (Rousseeuw, 1987). This index combines both cohesion, based on the average distances between all the objects in a cluster, and separation, based on the average distance of any object to all the other objects not contained in the same cluster. The range can lie between the value of -1 and +1 ; values below 0 are indicative of inappropriate fit, values between 0 and 0.2 indicate poor it, values between 0.2 and 0.5 indicate fair fit, while those above 0.5 suggest a good fit.

\section{Research results}

The optimal number of clusters of strategic business model typologies revealed in the data set of seven variables across 117 firms, was five. The distinguishing features of each of these five strategic approaches is discussed through representative case study examples, below.

\subsection{Optimal cluster number}

A compliment of SPSS cluster analysis solutions for the seven business model variables was generated, ranging from a cluster of one, where all typologies were lumped together, to fifteen clusters, where the range of types was large but the differences between them were tiny, and thus uninformative. Clusters may be considered categories into which objects may be classified. However, while categories come pre-labeled with what can and cannot be included within them, clusters work the opposite way, grouping items that share similarities, with the emerging similarities then percolating together to generate a descriptive label. What remains is to determine the most useful number of clusters to be extracted from the complement of solutions. The number should not be too large that the differences between items within clusters is virtually indistinguishable, and not too few that the differences are so polarized that variety is lost (Fraley \& Raftery, 1998). The number can be chosen intuitively, responding to the needs of the analysis for identifying key typologies. However, it can also be determined statistically, by looking for the cluster set with maximal inter-cluster differences, and minimal intra-cluster differences. The Schwarz BIC operation achieves this objective, and the operation identifies the optimal number of clusters to be five. At five clusters, the inter-cluster ratio of distance measures is 1.549 , the intra-cluster ratio is 0.311 (see Table 2). In verifying this result, a silhouette coefficient of goodness of fit of 0.30 was achieved.

Table 2. Schwarz's Bayesian information criterion for the determination of the optimal number of clusters

\begin{tabular}{|c|c|c|c|c|}
\hline $\begin{array}{c}\text { Number of } \\
\text { clusters }\end{array}$ & $\begin{array}{c}\text { Schwarz's Bayesian information } \\
\text { criterion (BIC) }\end{array}$ & BIC change ${ }^{a}$ & Ratio of BIC changes ${ }^{b}$ & $\begin{array}{c}\text { Ratio of distance } \\
\text { measures }^{c}\end{array}$ \\
\hline 1 & 3435.351 & - & - & 1.000 \\
\hline 2 & 2965.696 & -469.655 & 0.654 & 1.403 \\
\hline 3 & 2658.389 & -307.306 & 0.338 & 1.584 \\
\hline 4 & 2499.766 & -158.623 & 0.311 & 1.052 \\
\hline 5 & 2353.658 & -146.108 & 0.128 & 1.001 \\
\hline 6 & 2293.357 & -60.301 & 0.128 & 1.231 \\
\hline 7 & 2233.150 & -60.207 & 0.066 & 1.160 \\
\hline 8 & 2202.264 & -30.885 & 0.029 & 1.105 \\
\hline 9 & 2188.877 & -13.388 & 0.006 & 1.199 \\
\hline 10 & 2185.910 & -2.966 & -0.029 & 1.125 \\
\hline 11 & 2199.344 & 13.434 & -0.048 & 1.001 \\
\hline 12 & 2221.933 & 22.589 & -0.048 & 1.061 \\
\hline 13 & 2244.584 & 22.651 & -0.057 & 1.017 \\
\hline 14 & 2271.461 & 26.878 & -0.060 & 1.355 \\
\hline 15 & 2299.496 & 28.034 & & \\
\hline
\end{tabular}

a The changes are from the previous number of clusters in the table.

$\mathrm{b}$ The ratios of changes are relative to the change for the two cluster solution.

${ }^{\mathrm{c}}$ The ratios of distance measures are based on the current number of clusters against the previous number of clusters. 


\subsection{Taxonomy of five strategic business model typologies, and exemplar cases}

The two-step cluster analysis operation over five variables, across 117 real-estate firms, reveals five strategic business model typologies. These are the 1) commercial property model, 2) government servicing model, 3) cost efficiency model, 4) asset management model, and, 5) high turnover model. Firm numbers are fairly evenly distributed between these five types, at 18 (15.4\%), 26 (22.2\%), 20 (17.1\%), 31 (26.5\%), and $22(18.8 \%)$, respectively. The ratio of sizes comparing the largest to smallest cluster was 1.72. Figure 2-9 illustrate the cumulative distribution of the building cases, grouped into the five revealed clusters, against the seven critical variables (for more details, see the Appendix 2). A discussion of exemplar cases of each of the five strategic profiles follows.

\subsection{Cluster 1 - commercial property model}

There were 18 enterprise cases (15.4\% of 117) falling into Cluster 1, which is populated by peer-to-upstream cooperative (72.2\%), internally capable (55.6\%), risk-neutral (77.8\%), commercial orientated (66.7\%), regional (100\%) enterprises, with sales (66.7\%) targeting high-end customers $(72.2 \%)$.

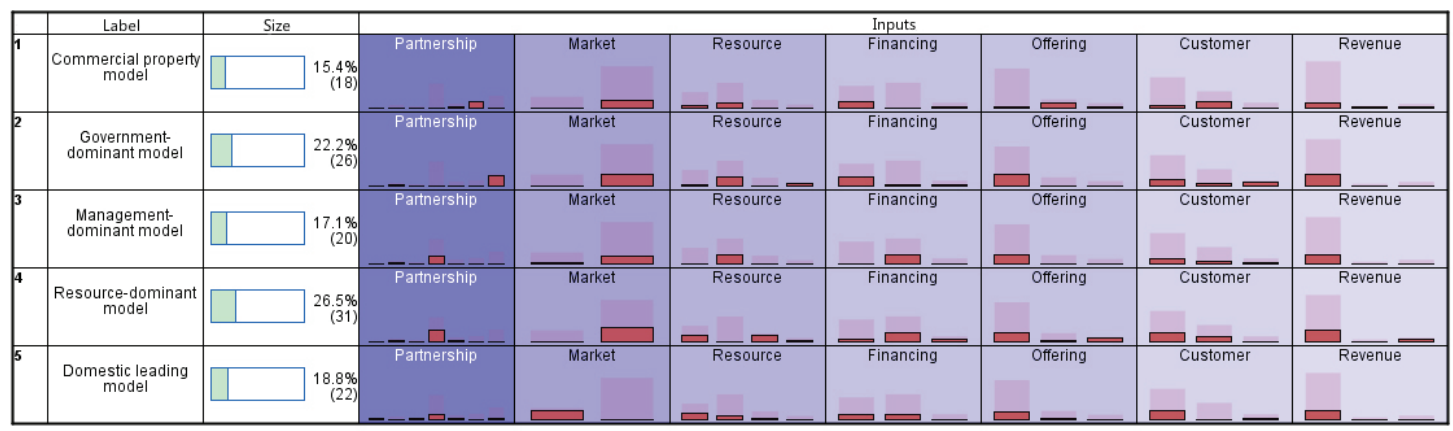

Figure 2. Taxonomy of five strategic business model types used by firms operating in the Chinese real-estate industry

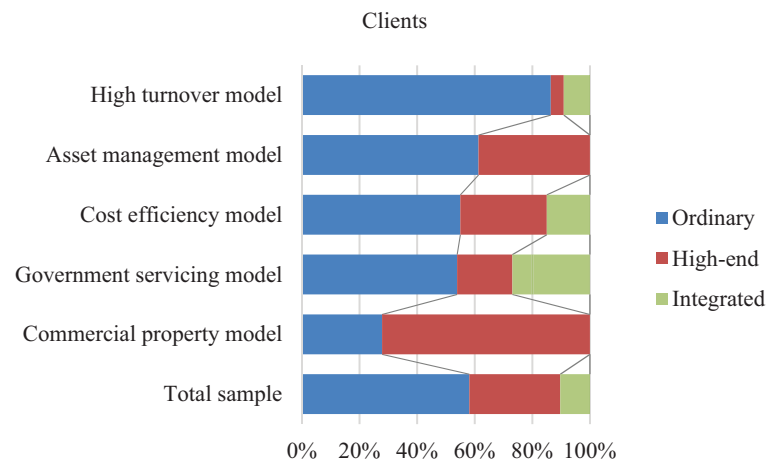

Figure 3. Distribution of the cases in the total sample and the five revealed clusters against the variable of clients

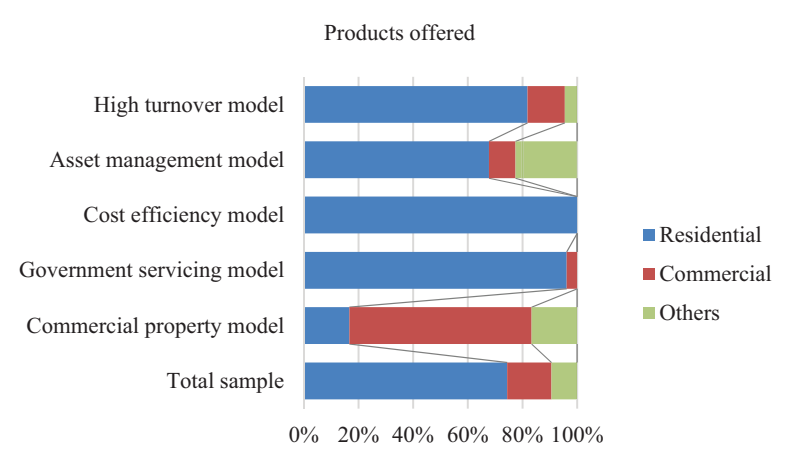

Figure 4. Distribution of the cases in the total sample and the five revealed clusters against the variable of product offered

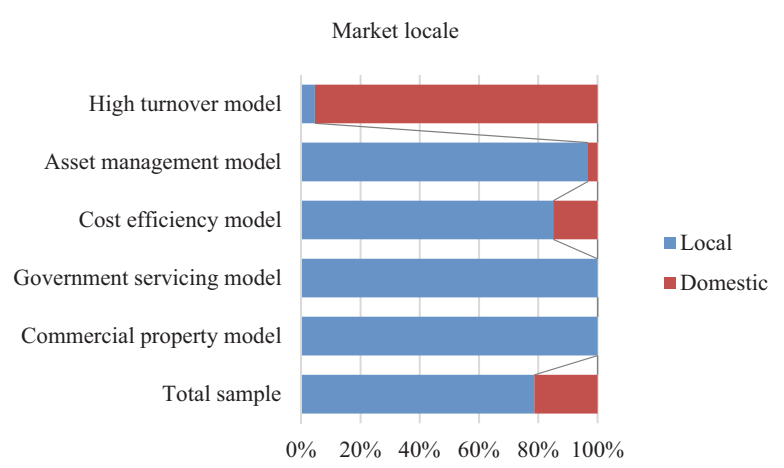

Figure 5. Distribution of the cases in the total sample and the five revealed clusters against the variable of market locale

Financial structure

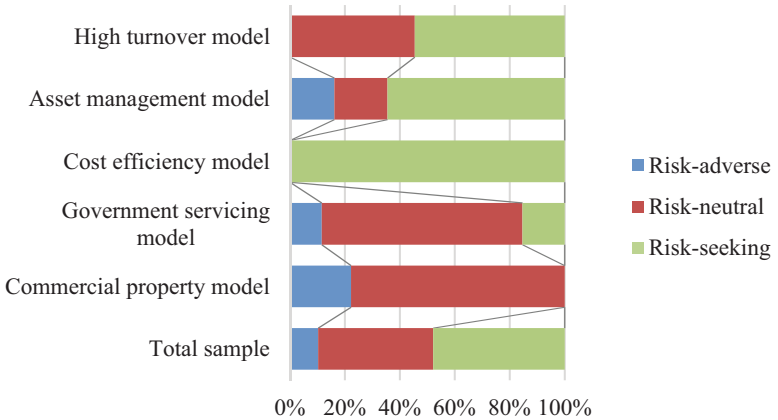

Figure 6. Distribution of the cases in the total sample and the five revealed clusters against the variable of financial structure 


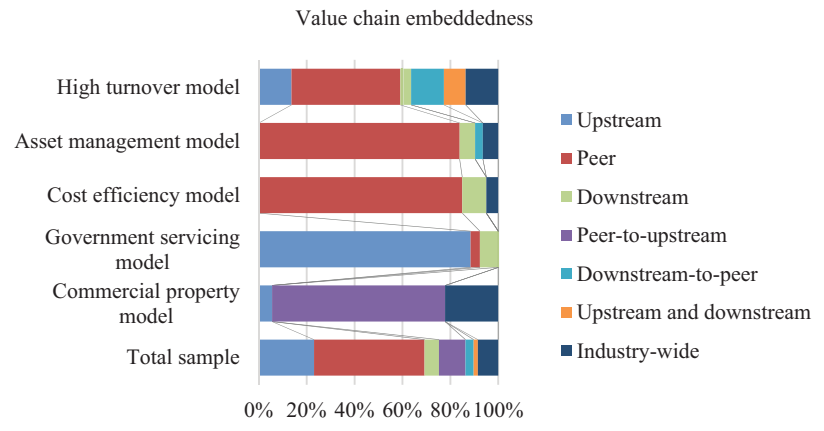

Figure 7. Distribution of the cases in the total sample and the five revealed clusters against the variable of value chain embeddedness

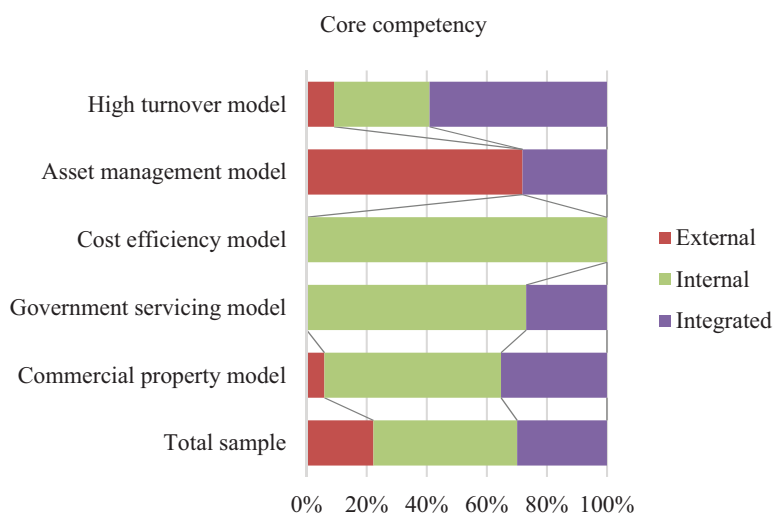

Figure 8. Distribution of the cases in the total sample and the five revealed clusters against the variable of core competency

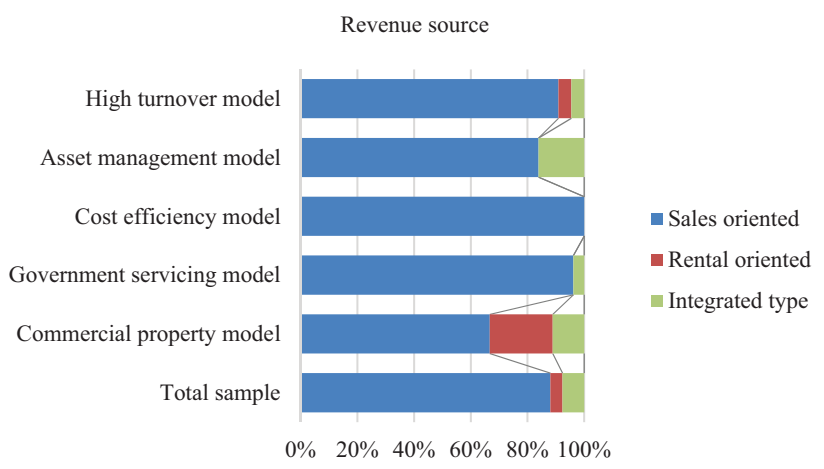

Figure 9. Distribution of the cases in the total sample and the five revealed clusters against the variable of revenue source

Firms in Cluster 1 can best be described as regional commercial property developers. The main product offered by these firm are commercial property including retailers of all kinds, e.g., office space, hotels, strip malls, restaurants and convenience stores. As their business strategies, these firms place emphasis on peer-to-upstream cooperation and internal capability. In other words, these firms engage with upstream stakeholders (such as governments and financial institutions) and peer stakeholders (such as designers and contractors), and their competitive advantage typically relied on their self-generated management and technological capabilities, including human resources, life cycle management as well as financial and systems controls. In terms of value acquisition, the main source of income of firms in Cluster 1 come from property sales to high-income clients.

Cluster 1 - Case - Dalian Wanda Group: The Dalian Wanda Group, was established in 1988 as a real-estate company and operates in four major industries: commercial property, luxury hotels, culture and tourism, and department stores. It is the first real-estate company in China to shift completely to commercial real-estate.

Cluster 1 - Value orientation: The Wanda Commercial Properties of the Wanda Group is a global leader in the field of commercial real-estate. Wanda Commercial Properties consists of a business planning and research institute, national commercial real-estate construction team, and a national business management company, all of which form a full industry chain giving it a competitive advantage in its industry. As of January 2016, it had a portfolio of 133 Wanda Plazas across China. The Wanda Plaza concept relates to the development of a multifunctional urban complex that incorporates five star hotels, department stores, shopping malls, office buildings, apartments, restaurants and cinemas.

Cluster 1 - Value creation: The profits of Wanda Commercial Properties are generated from sales and rental of properties. This approach has two benefits. Firstly, the Wanda Group acquires land adjacent to its Wanda Plazas, to build residential or office buildings, and does so for a low price negotiated with the local government. They obtain the low price based on the benefits of the longterm operation of the Wanda Plaza. Secondly, properties around the Wanda Plaza will appreciate in value, mainly because of the brand influence and appeal of the Wanda Plaza. Consequently, the Wanda Group shares its profits with the participants within its collaborative network, such as government, banks and merchants.

Cluster 1 - Value source: (1) rental of commercial properties; (2) sales of shops and residential properties; and (3) operating revenue of five star hotels and Wanda Cinemas.

\subsection{Cluster 2 - government servicing model}

There were 26 enterprise cases (22.2\% of 117$)$ falling into Cluster 2, which is populated by upstream cooperative (88.5\%), internally capable (73.1\%), risk-neutral (73.1\%), residential oriented $(96.2 \%)$, regional (100\%) enterprises, with sales (96.2\%) targeting ordinary customers (53.8\%).

Most firms in Cluster 2 are state-owned enterprises (SOEs), responsible for urban infrastructure construction and the provision of public services including roads, bridges, water utilities, and real-estate, etc. The natural cooperation with the government was a defining characteristic of the firms in Cluster 2. Specifically, these firms undertake projects invested by the government, and their competitive advantage comes from enjoying preferential tax treatment. Government grants serve as the main source of revenue for these firms. The 'build-operate- 
transfer' (BOT) model is also a major financing method for these SOEs, especially in their core urban infrastructure business.

Cluster 2 - Case - Shanghai Municipal Investment Group (SMI): The SMI was established in 1992 as a stateowned enterprise, and operates in urban infrastructure industries: building roads, bridges, water utilities, and real-estate. SMI enjoys preferential tax and land treatment, as the company is owned and controlled by government.

Cluster 2 - Value orientation: As the first municipal investment company in China, SMI recently switched its role downstream from being a financing platform of government led construction, to a solution provider of urban infrastructure and public services. SMI operates four major real-estate businesses niches in Shanghai, including new zone development, urban renewal, preservation and restoration of historic buildings, and commercial housing construction.

Cluster 2 - Value creation: SMI, as delegated by the local government, has the responsibility for investing, constructing and operating urban infrastructure in Shanghai. The 'build-operate-transfer' (BOT) model is a major financing method applied to urban infrastructure construction by SMI. Apart from its core urban infrastructure business, SMI is also acquiring other real-estate related businesses through capital investment.

Cluster 2 - Value source: (1) investment by government in grants and tax relief; (2) social funds obtained for BOT projects; and (3) sales of commercial residences.

\subsection{Cluster 3 - cost efficiency model}

There were 20 enterprise cases (17.1\% of 117) falling into Cluster 3, which is populated by peer cooperative (85.0\%), internally capable (100\%), risk-seeking (100\%), residential oriented (100\%), regional (85.0\%) enterprises, with sales (100\%) targeting ordinary customers (55.0\%).

Firms in Cluster 3 have strong management capabilities in areas related to real-estate, which includes cost management, property management, property agency management, logistic operations and building design consultancy services, etc. The business strategies of firms in this cluster are primarily based on two aspects. Firstly, their top priority is systematic cost management, which maintains their advantage over competitors through reduced operational costs that are lower than other firms in the real-estate industry in China. Secondly, their housing prices are set relatively higher than that offered by other firms. High prices are reflected in high quality products and services, which are achieved via strong independent development ability across the whole industry chain. As for value acquisition, they gain high profits from lean operations and cost leadership strategies.

Cluster 3 - Case - The China Overseas Property Group (COPG): The COPG is the subsidiary of the China State Construction Engineering Corporation (CSCEC), and was incorporated in Hong Kong, in 1979. It is engaged in construction and contracting, property development and infrastructure investment.
Cluster 3 - Value orientation: China Overseas operates in three segments: (1) property development, specializing in the development and sales and letting of residential properties for mostly high-end customers; (2) infrastructure investment, focusing mostly in entities undertaking toll highways; and (3) other operations in highly specialized management related areas, such as property management, property agency management, logistics operations, and building design consultancy services. China Overseas' property development, infrastructure investment and other activities are carried out in Hong Kong and Macau, as well as in regions across the Chinese mainland, though all infrastructure project investments are located in the China proper.

Cluster 3 - Value creation: China Overseas has a strong independent development ability across the whole industry chain. CSCEC is a Chinese construction company ranked the 3rd largest in the world, and is the first largest general contractor in China. As a subsidiary of CSCEC, China Overseas has successfully controlled land acquisition costs and maintains strict control of the cost and quality of its property developments. Moreover, lean operations and cost leadership strategies remain an overriding priority in the enterprise management of China Overseas. It operates systematic cost control systems over the various sections of its business operations, and maintains its advantage over competitors by reducing operational costs below that of others in the real-estate industry in China.

Cluster 3 - Value source: (1) cost leadership strategies are used by China Overseas to maintain low cost of operations; and (2) sales of highly profitable residential properties.

\subsection{Cluster 4 - Asset management model}

There were 31 enterprise cases (26.5\% of 117) falling into Cluster 4 , which is populated by peer cooperative $(83.9 \%)$, externally capable (48.4\%), risk-seeking (64.5\%), residential oriented (67.7\%), regional (96.8\%) enterprises, with sales $(83.9 \%)$ targeting ordinary customers $(61.3 \%)$.

The distinguishing characteristic of firms in Cluster 4 is related to strong access to financial resources in real-estate businesses. These firms formulate their business strategies around real-estate financing and commercial real-estate operations. The core capability of these firms lies in their close cooperation with financial institutions, e.g., commercial banks, insurance companies, asset management companies, trust companies, securities companies, public fund offering enterprises. The close-knit relationships with financial institutions provide them with a strong platform for real-estate investments and asset management. Accordingly, these firms generate revenue primarily from their financial businesses and property operations.

Cluster 4 - Case - Gemdale Group: The Gemdale Group, was founded in 1988 and is headquartered in Shenzhen, China. It moved into real-estate business operations in 1993. In 2006, Gemdale branched out into the financial side of real-estate, becoming one of the first realestate companies engaged in this sector. 
Cluster 4 - Value orientation: In 2010, Gemdale formulated the "one core business and two branches" strategy in an effort to focus on residential real-estate as the core business, augmented financial business and commercial real-estate as its secondary areas of operations. Currently, Gemdale's businesses include development and sales of residences, development, sales and operation of commercial real-estate, real-estate financing, property services and facilities management.

Cluster 4 - Value creation: Gemdale drew on its financial resources to fund its expansion into the real-estate business. Gemdale's core capability lies in its close cooperation with financial institutions. Gemdale has established partnerships with commercial banks, insurance companies, asset management companies, trust companies, securities companies, public fund offering enterprises, and other financial institutions. Wins Investment is the realestate private equity management company established by Gemdale. As a real-estate fund management platform of Gemdale, its core competitiveness lies in real-estate investment, product research and development, and asset management. Wins is listed as one of the 'Top 10' Chinese real-estate funds, released ranked by both the Zero2IPO Group and China Venture.

Cluster 4 - Value source: (1) sales of properties; and (2) real-estate financing.

\subsection{Cluster 5 - High turnover model}

There were 22 enterprise cases (18.8\% of 117) falling into Cluster 5, which is populated by peer cooperative (45.5\%), comprehensively capable (59.1\%), risk-seeking (54.5\%), residential oriented $(81.8 \%)$, nationwide $(95.5 \%)$ enterprises, with sales $(90.9 \%)$ targeting ordinary customers (86.4\%).

Cluster 5 represents the firms with a high degree of real-estate business turnover. With the implementation of the high-speed expansion strategy, these firms have rapidly acquired a large range of projects both regionally and nationally. They have done this mainly by utilizing a standardized system of operations, including project selection, planning and design, material selection, bidding, engineering management and marketing, which minimizes their business risk, and at the same time, facilitates in effectively controlling costs and delivering high-quality products. The target consumers for these firms are 'first home buyers' and middle class 'owner-occupiers' that make up a large and stable market for housing. Thus, Medium-end and medium-to-high-end products accounts for majority of their sales revenue.

Cluster 5 - Case - Evergrande Group: The Evergrande Group, was founded in the southern Chinese city of Guangzhou in 1996. Since 2004, with the implementation of the national development strategy for high-speed expansion, it has rapidly achieved a nationwide spread of projects utilizing a standardized system of operation and products. Presently, Evergrande has built over 500 large projects across more than 180 major cities within China, delivered by more than 20 localized subsidiaries founded by the Group.

Cluster 5 - Value orientation: Evergrande implemented its own particular development strategy of "scale + brand," and with it, expanded out from Guangzhou to the whole country. Evergrande's projects are generally located in the cities' high quality areas, where demand for housing is high, and which already have mature supporting facilities, developed urban transportation, and great capital appreciation potential. Evergrande's product positioning is aimed at 'first home buyers' and middle class 'owner-occupiers.' These medium-end products and the medium-tohigh-end products account for $70 \%$ of sales revenue, with tourist real-estate products a further 15\%, and high-end products accounting for the remaining 15\%.

Cluster 5 - Value creation: Evergrande is a real-estate enterprise with the largest land reserves in China. Its projects are based in regional cities and economic centers where there is a huge residual and stable demand for housing, potential for large economies of scale in construction, and ongoing economic growth. Evergrande follows the mode of standardized operation. Through collectivized management, the Group is able to implement standardized systems of management across it regional network of companies, nationwide. Seven management modes stand out, including, project selection, planning and design, use of materials, bidding, engineering management, and marketing. Standardization of practices across these activities minimize the business risk resulting from nationwide expansion, and facilitates the effective control of cost and the creation of high-quality products.

Cluster 5 - Value source: (1) rapid sales of residential properties, based on a 'small area, low price' strategy.

\section{Conclusions}

A successful strategy lies at the heart of every successful business. Indeed, strategic studies and strategic issues have dominated discourse in business management, both academically and in practice, for over fifty years now since it emerged at the Harvard Business School in the mid 1960s. The business model is the working expression of a firm's business strategy. Over the decades, since China's opening up in the late seventies, the real-estate industry has figured prominently in China's economic rise, providing the infrastructure, commercial property and utilities on which China's GDP growth has depended. Yet, in all this time, there has been almost no research conducted to uncover the strategies used by Chinese firms within the economically pivotal real-estate sector. An understanding of how real-estate firms compete, and achieve, defend and maintain strategic advantage is long overdue; particularly given that the period of China's rise may be reaching a plateau, and that management will require deeper insights into how firms source and sustain competitive advantage when inevitable recessionary pressures begin to emerge to cull competitors from the real-estate industry. 
This study addresses this need to identify the strategic business models used by firms' active in the Chinese real-estate industry. Seven variables that inform business models were identified, and 117 enterprises active in the Chinese real-estate industry were approached and studied through questionnaire surveys and by analyzing relevant documents. A two-step cluster analysis was applied to the data, with a taxonomy of five strategic business models extracted. These were the 1) commercial property model, 2) government servicing model, 3) cost efficiency model, 4) asset management model, and, 5) high-turnover model. Practitioners, managers and academics alike, will find these models insightful in furthering their understanding of how firm's find and maintain the strategic advantage necessary to profitability and survival in the highly competitive Chinese real-estate industry.

The implications of this study for practitioners are significant. Competent management will be well aware that choices must be made as to clients served, products offered, markets targeted, financial structure designed, degree of value-chain embeddedness, core competency pursued and, perhaps above all, selected revenue stream. However, no strategy can be expected to be successful when these factors are considered in isolation. Strategic success is dependent on the synergy generated from the interplay of all these variables, in combination. Whether any particular client base or market niche will confer advantage to a firm will depend on the choices available and the choices made regarding the other variables. What might be right in one setting, may be wrong in another. The value of this study is that it reveals five successful strategies evident in the Chinese real-estate industry. By examining the 'fine-tuning' of the seven identified variables within the five revealed strategies - strategies that are demonstrably successful - real-estate practitioners will be better equipped to determine the right strategy for their own enterprises.

However, it needs to be noted that business models that are influenced by 'relationships with the government' may apply in the case of all five clusters. Political connections, to a large extent, is an important parameter related to business strategies in China (Liu, Luo, \& Tian, 2016a; Liu, Luo, \& Tian, 2016b). Political connection may cut across the identified five clusters, not just the governmentservicing cluster. Thus, future studies may specifically focus on this area to determine how this parameter defines business models in China.

\section{Acknowledgements}

This study was supported by the National Natural Science Foundation of China (Grant No. 71802030), the China Postdoctoral Science Foundation (Grant No. 2017M620416) and the National Key Research and Development Program (Grant No. 2016YFC0701807). The author would like to thank the Editors and the anonymous referees for their helpful comments on earlier versions of this article.

\section{References}

Abdelkafi, N., Makhotin, S., \& Posselt, T. (2013). Business model innovations for electric mobility - what can be learned from existing business model patterns?. International Journal of Innovation Management, 17(1), 1-41. https://doi.org/10.1142/S1363919613400033

Ball, M. (2010). The housebuilding industry: promoting recovery in housing supply. Department for Communities \& Local Government (DCLG), London.

Barney, J. B. (1991). Firm resources and sustained competitive advantage. Journal of Management, 17(1), 99-120. https://doi.org/10.1177/014920639101700108

Brege, S., Stehn, L., \& Nord, T. (2014). Business models in industrialized building of multi-storey houses. Construction Management and Economics, 32(1), 208-226. https://doi.org/10.1080/01446193.2013.840734

Brettel, M., Strese, S., \& Flatten, T. C. (2013). Improving the performance of business models with relationship marketing efforts - an entrepreneurial perspective. European Management Journal, 30(2), 85-98. https://doi.org/10.1016/j.emj.2011.11.003

Casadesus-Masanell, R., \& Zhu, F. (2010). Strategies to fight ad-sponsored rivals. Management Science, 56(9), 1484-1499. https://doi.org/10.1287/mnsc.1100.1199

Callcutt, J. (2007). The Callcutt review of housebuilding delivery. Department for Communities \& Local Government (DCLG), London.

Chesbrough, H. (1996). Business model innovation: it's not just about technology anymore. Strategy \& Leadership, 35(6), 1217. https://doi.org/10.1108/10878570710833714

Dahan, N. M., Doh, J. P., Oetzel, J., \& Yaziji, M. (2010). Corporate-NGO collaboration: co-creating new business models for developing markets. Long Range Planning, 43(2-3), 326-342. https://doi.org/10.1016/j.lrp.2009.11.003

Dasilva, C. M., \& Trkman, P. (2014). Business model: what it is and what it is not. Long Range Planning, 47(6), 379-389. https://doi.org/10.1016/j.lrp.2013.08.004

Doganova, L., \& Eyquem-Renault, M. (2009). What do business models do?: Innovation devices in technology entrepreneurship. Research Policy, 38(10), 1559-1570.

https://doi.org/10.1016/j.respol.2009.08.002

Fellows, R. F., \& Langford, D. A. (1980). Decision theory and tendering. Building Technology and Management, 45(1), 3649.

Fraley, C., \& Raftery, A. E. (1998). How many clusters? Which clustering method? Answers via model-based cluster analysis. The Computer Journal, 41(8), 578-588.

https://doi.org/10.1093/comjnl/41.8.578

Goodier, C., \& Pan, W. (2011). The challenges for UK housebuilding. RICS Residential Property Journal, May-June (2011), 4-7.

Hamel, G. (1998). The challenge today: changing the rules of the game. Business Strategy Review, 9(9), 19-26. https://doi.org/10.1111/1467-8616.00062

Johnson, M. W., Christensen, C. M., \& Kagermann, H. (2008). Reinventing your business model. Harvard Business Review, $87(12), 52-60$.

Lambert, S. C., \& Davidson, R. A. (2013). Applications of the business model in studies of enterprise success, innovation and classification: an analysis of empirical research from 1996 to 2010. European Management Journal, 31(6), 668-681. https://doi.org/10.1016/j.emj.2012.07.007 
Li, H., Guo, H., Skibniewski, M. J., \& Skitmore, M. (2008). Using the IKEA model and virtual prototyping technology to improve construction process management. Construction Management and Economics, 26(9), 991-1000. https://doi.org/10.1080/01446190802290477

Li, K. J., Zhou, Y., Shrestha, A., \& Liu, G. W. (2018). A cluster analysis of real estate business models in China. Proceedings of the 21st International Symposium on Advancement of Construction Management and Real Estate. Singapore: Springer. https://doi.org/10.1007/978-981-10-6190-5_1

Liu, Q., Luo, J., \& Tian, G. (2016a). Managerial professional connections versus political connections: evidence from firms' access to informal financing resources. Journal of Corporate Finance, 41, 179-2000. https://doi.org/10.1016/j.jcorpfin.2016.09.003

Liu, Q., Luo, J., \& Tian, G. (2016b). Political connections with corrupt government bureaucrats and corporate M\&A decisions: a natural experiment from the anti-corruption cases in China. Pacific Basin Finance Journal, 37, 52-80. https://doi.org/10.1016/j.pacfin.2016.03.003

Liu, G. W., Li, K. J., Zhao, D., \& Mao, C. (2017). Business model innovation and its drivers in the Chinese construction industry during the shift to modular prefabrication. Journal of Management in Engineering, 3(33).

https://doi.org/10.1061/(ASCE)ME.1943-5479.0000501

Magretta, J. (2002). Why business model matter. Harvard Business Review, 80(5), 86-92.

Martek, I., \& Chen, C. (2014). Competitive strategies associated with particular localization patterns adopted by implanted architecture, engineering, and construction firms in China. Journal of Management in Engineering, 30(4), 1-13. https://doi.org/10.1061/(ASCE)ME.1943-5479.0000232

Martek, I. \& Chen, C. (2013). Localization typologies evident amongst foreign enterprises active in the Chinese construction market. Journal of Construction Engineering and Management, 139(10), 1-12.

https://doi.org/10.1061/(ASCE)CO.1943-7862.0000719

Mangematin, V., Ravarini, A. M., \& Scott, P. S. (2017). Practitioner insights on business models and future directions. Journal of Business Strategy, 38(2), 3-5. https://doi.org/10.1108/JBS-10-2016-0130

Moore, G. A. (2004). Darwin and the demon: innovating within established enterprises. Harvard Business Review, 82(7), 86-99.

Morris, M., Schindehutte, M., \& Allen, J. (2005). The entrepreneur's business model: toward a unified perspective. Journal of Business Research, 58(6), 726-735.

https://doi.org/10.1016/j.jbusres.2003.11.001

Osterwalder, A., \& Pigneur, Y. (2005). Clarifying business models: origins, present, and future of the concept. Communications of the Association for Information Systems, 16(16), 751775.

Ovans, A. (2015). What is a business model?. Harvard Business Review, 27, 167-178.

Pan, W., \& Goodier, C. (2012). House-building business models and off-site construction take-up. Journal of Architectural Engineering, 18(2): 84-93. https://doi.org/10.1061/(ASCE)AE.1943-5568.0000058

Pekuri, A., Suvanto, M., Haapasalo, H., \& Pekuri, L. (2014). Managing value creation: the business model approach in construction. International Journal of Business Innovation \& Research, 2014(1), 36-51.

https://doi.org/10.1504/IJBIR.2014.058045
Penrose, E. T. (1959). The theory of the growth of the firm. New York: John Wiley \& Sons.

Podsakoff, P. M., Mackenzie, S. B., Lee, J. Y., \& Podsakoff, N. P. (2003). Common method biases in behavioral research: a critical review of the literature and recommended remedies. Journal of Applied Psychology, 88(5), 879-903. https://doi.org/10.1037/0021-9010.88.5.879

Porter, M. (1985). Competitive advantage: creating and sustaining superior performance. New York: Free Press.

Rousseeuw, P. J. (1987). Shilhouettes: a graphical aid to the interpretation and validation of cluster analysis. Journal of Computational \& Applied Mathematics, 20(1987), 53-65. https://doi.org/10.1016/0377-0427(87)90125-7

Seaden, G., Guolla, M., Doutriaux, J., \& Nash, J. (2003). Strategic decisions and innovation in construction firms, Construction Management and Economics, 21(21), 603-612. https://doi.org/10.1080/0144619032000134138

Schaltegger, S., Lüdeke-Freund, F., \& Hansen, E. G. (2013). Business cases for sustainability. International Journal of Innovation and Sustainable Development, 6(2), 95-119. https://doi.org/10.1504/IJISD.2012.046944

Shafer, S. M., Smith, H. J., \& Linder, J. C. (2005). The power of business models. Business Horizons, 48(3), 199-207. https://doi.org/10.1016/j.bushor.2004.10.014

Smith, W. K., Binns, A., \& Tushman, M. L. (2010). Complex business models: managing strategic paradoxes simultaneously. Long Range Planning, 43(2-3), 448-461. https://doi.org/10.1016/j.lrp.2009.12.003

Sako, M. (2012). Business models for strategy and innovation. Communications of the ACM, 55(7), 22-24. https://doi.org/10.1145/2209249.2209259

Teece, D. J. (2010). Business models, business strategy and innovation. Long Range Planning, 43(2-3), 172-194. https://doi.org/10.1016/j.lrp.2009.07.003

Thomas, R. (2001). Business value analysis: coping with unruly uncertainty. Strategy and Leadership, 29(2), 16-24. https://doi.org/10.1108/10878570110695129

Timmers, P. (1998). Business models for electronic markets. Electronic Markets, 8, 3-8. https://doi.org/10.1080/10196789800000016

Tykkä, S., et al. (2010). Development of timber framed firms in the construction sector: Is EU policy one source of their innovation? Forest Policy \& Economics, 12(3), 199-206. https://doi.org/10.1016/j.forpol.2009.10.003

Voelpel, S., Leibold, M., \& Tekie, E. (2004). The wheel of business model to leapfrog competitors. Journal of Change Management, 4(3). https://doi.org/10.1080/1469701042000212669

Weng, J. Y. (2004). Mesoscopic business model: nano research of management areas. China Economic Studies, 2004(1), 34-40.

Wernerfelt, B. (1984). A resource-based view of the firm. Strategic Management Journal, 5(2), 171-180. https://doi.org/10.1002/smj.4250050207

Wirtz, B.W., Schilke, O., \& Ullrich, S. (2010). Strategic development of business models: implications of the web 2.0 for creating value on the internet. Long Range Planning, 43(2-3), 272-290. https://doi.org/10.1016/j.lrp.2010.01.005

Winterhalter, S., Weiblen, T., Wecht, C. H., \& Gassmann, O. (2017). Business model innovation processes in large corporations: insights from BASF. Journal of Business Strategy, 38(2), 62-75. https://doi.org/10.1108/JBS-10-2016-0116

Yuan, L. (2007). Reconstruction of business model. China Industrial Economy, 2007(6), 72-81. 


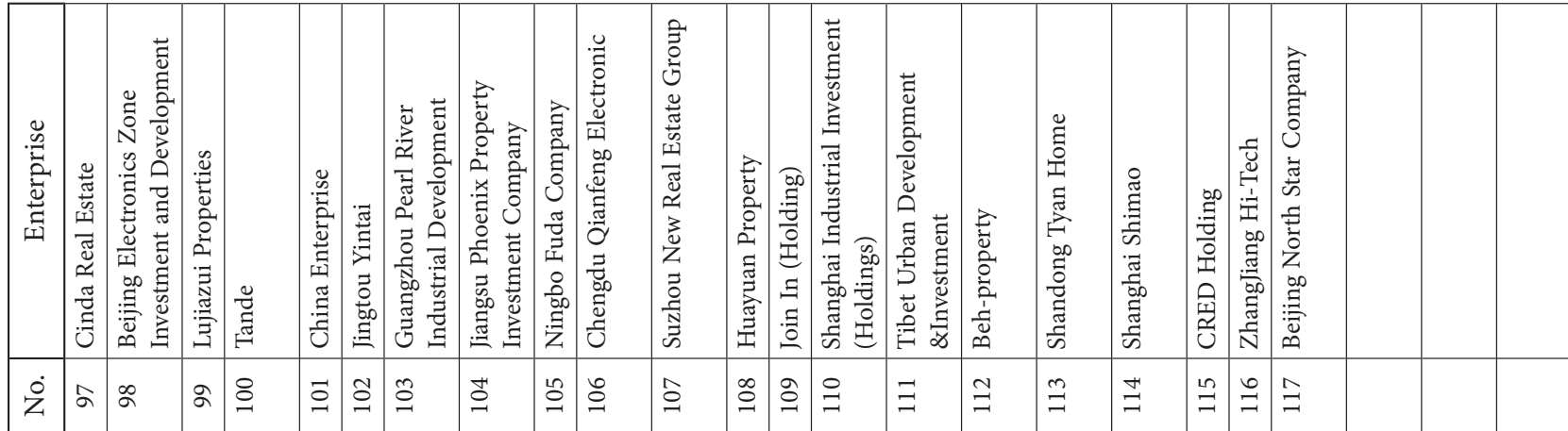

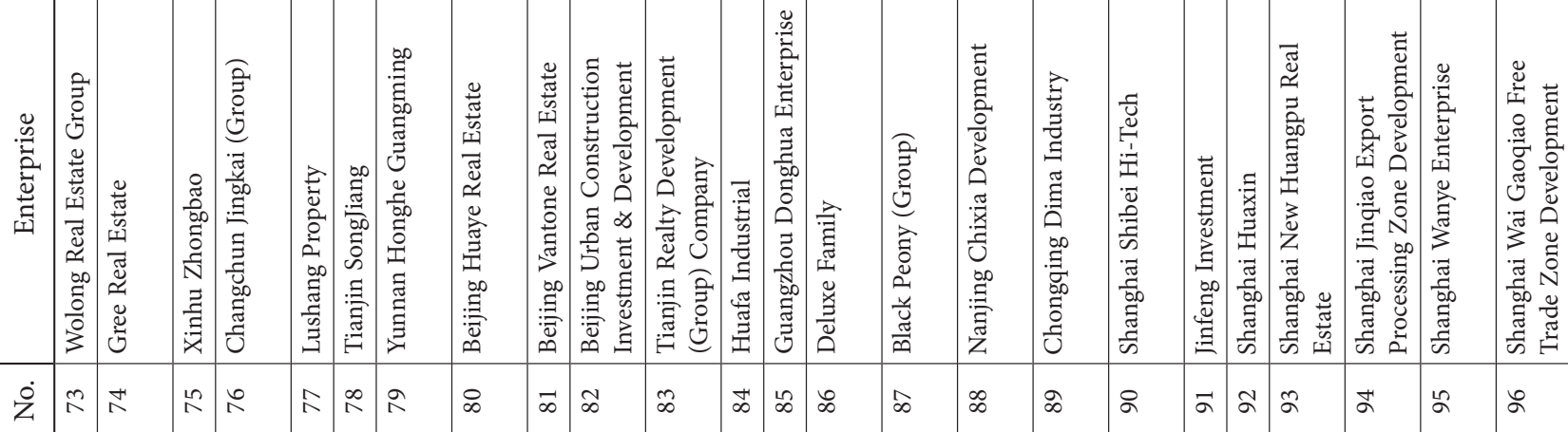

\begin{tabular}{|c|c|c|c|c|c|c|c|c|c|c|c|c|c|c|c|c|c|c|c|c|c|c|c|}
\hline 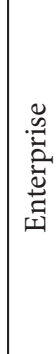 & 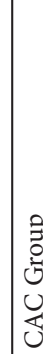 & 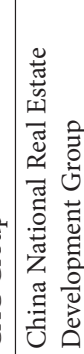 & 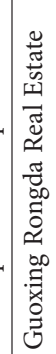 & 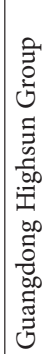 & 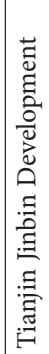 & 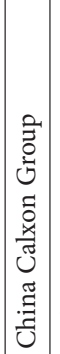 & 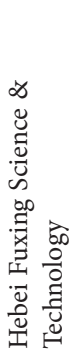 & 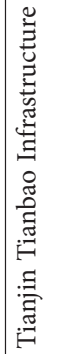 & 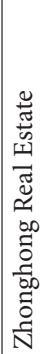 & 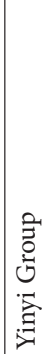 & 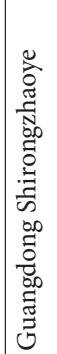 & $\begin{array}{l}3 \\
0 \\
0 \\
0 \\
0 \\
0 \\
\sum_{0} \\
0 \\
0\end{array}$ & 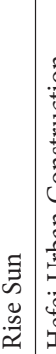 & 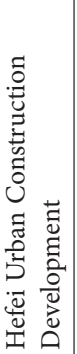 & 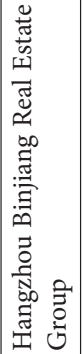 & 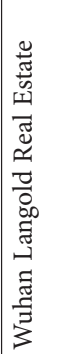 & 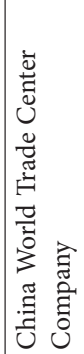 & 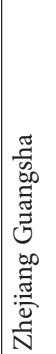 & 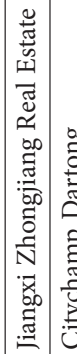 & 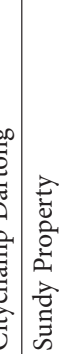 & 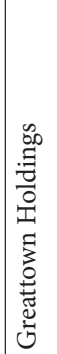 & 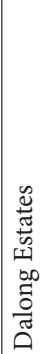 & 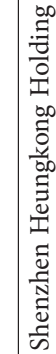 \\
\hline
\end{tabular}

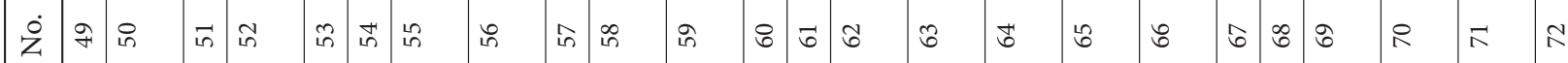

\begin{tabular}{|c|c|c|c|c|c|c|c|c|c|c|c|c|c|c|c|c|c|c|c|c|c|c|c|c|}
\hline 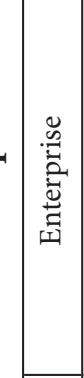 & 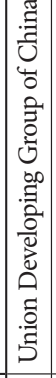 & 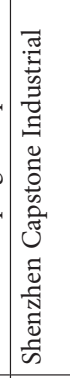 & 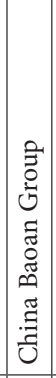 & 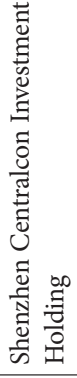 & 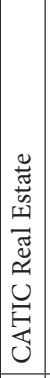 & 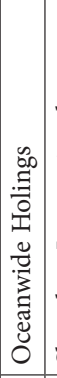 & 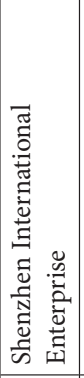 & 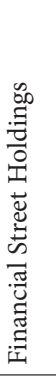 & 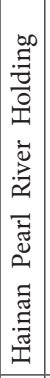 & 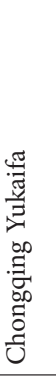 & 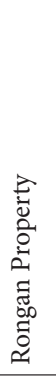 & 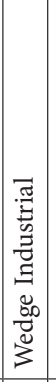 & 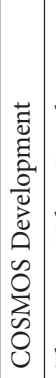 & 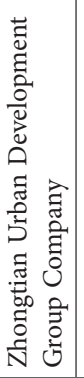 & 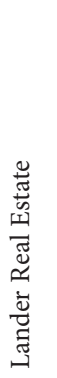 & 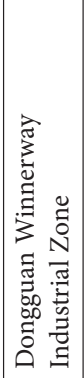 & 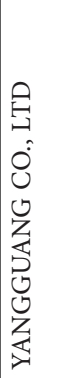 & 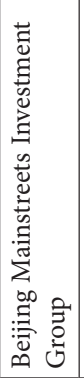 & 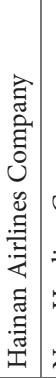 & 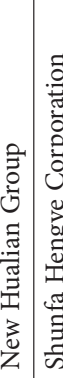 & 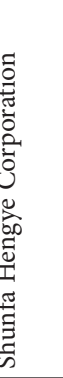 & $\begin{array}{l}\sum_{0}^{m} \\
0 \\
\sum^{2} \\
\sum \\
\sum\end{array}$ & 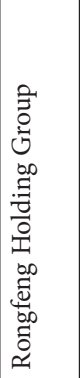 & $\begin{array}{l}\text { 品 } \\
\text { 氕 }\end{array}$ \\
\hline$\dot{z}$ & $\stackrel{\sim}{\sim}$ & $\stackrel{2}{1}$ & $\hat{\imath}$ & $\stackrel{\infty}{\sim}$ & $\grave{\curvearrowright}$ & i & $\vec{m}$ & $\tilde{m}$ & $m$ & 岑 & $\stackrel{\llcorner}{m}$ & $\infty$ & m & $\stackrel{\infty}{m}$ & ले & 우 & $F$ & F & $\Re$ & $F$ & $f$ & \& & f & $\stackrel{\infty}{\leftrightarrow}$ \\
\hline 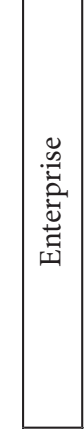 & 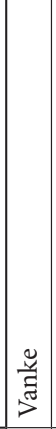 & 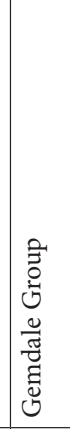 & 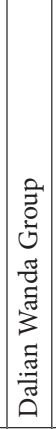 & 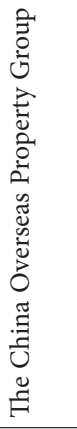 & 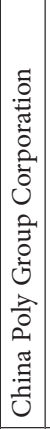 & 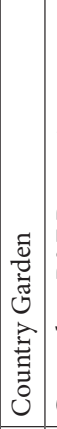 & 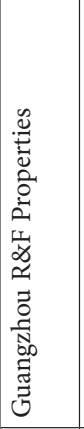 & 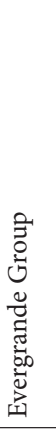 & 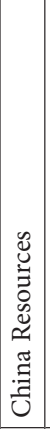 & 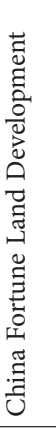 & 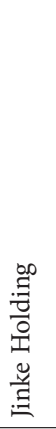 & 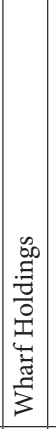 & 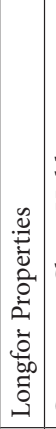 & 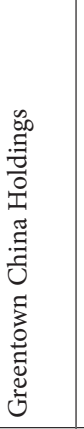 & 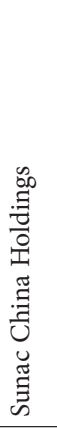 & 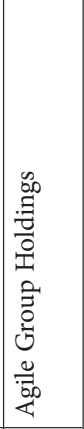 & 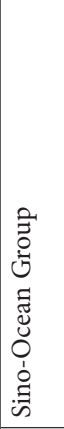 & 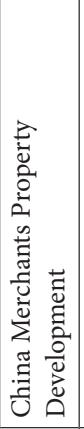 & 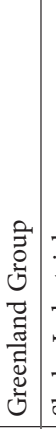 & 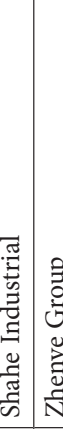 & 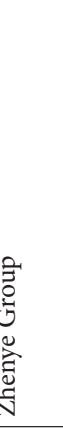 & 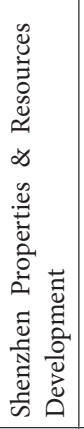 & 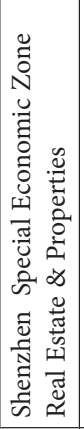 & 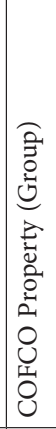 \\
\hline$\dot{z}$ & -7 & N & $m$ & $r$ & in & 0 & $\wedge$ & $\infty$ & $a$ & 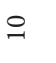 & $\exists$ & $\approx$ & 9 & 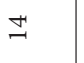 & $\stackrel{2}{9}$ & 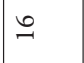 & $=$ & $\stackrel{\infty}{\rightarrow}$ & 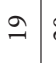 & $\bar{\sim} \bar{\sim}$ & $\vec{N}$ & $\approx$ & $\approx$ & $\underset{N}{\stackrel{H}{*}}$ \\
\hline
\end{tabular}




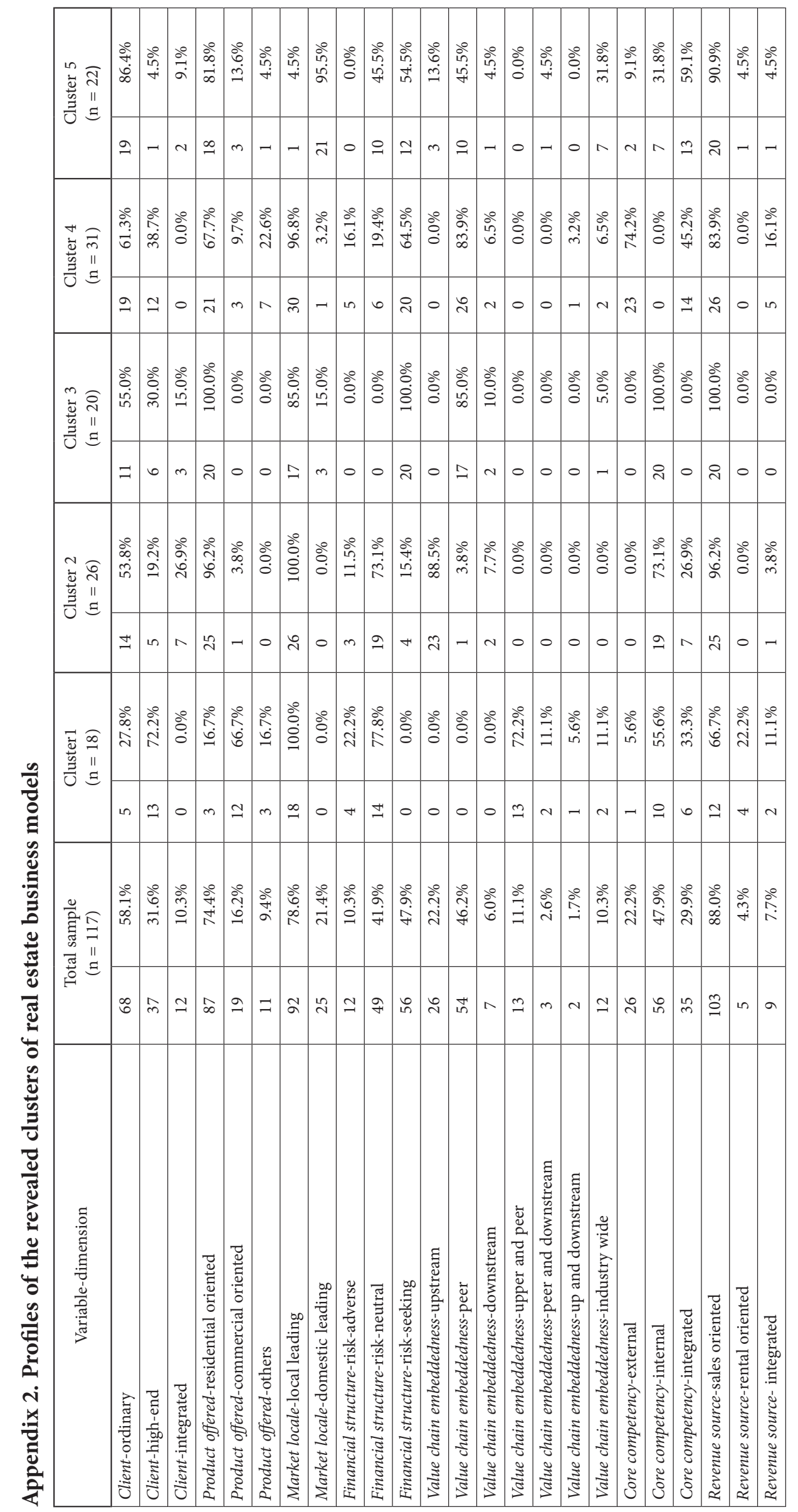

